\title{
Febrile Seizures in Idiopathic/Genetic Generalized and Self-Limited Focal Epilepsies
}

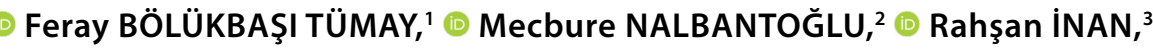 \\ Figen YAVLAL, ${ }^{4}$ (1) Veysi DEMIRBiLEK ${ }^{5}$
}

\author{
'Department of Neurology, Yeni İklim Private Hospital, İstanbul, Turkey \\ ${ }^{2}$ Department of Neurology, İstanbul Bilim University Faculty of Medicine, İstanbul, Turkey \\ ${ }^{3}$ Department of Neurology, University of Health Sciences, Kartal Dr. Lütfü Kırdar City Hospital, İstanbul, Turkey \\ ${ }^{4}$ Department of Neurology, Bahçesehir University Faculty of Medicine, İstanbul, Turkey \\ ${ }^{5}$ Department of Child Neurology, İstanbul University Cerrahpaşa Faculty of Medicine, İstanbul, Turkey
}

\begin{abstract}
Objectives: Febrile seizure (FS) is the most common form of childhood seizures. Furthermore, idiopathic/generalized and focal/self-limited epilepsies present at the similar age-range. They usually have a favorable outcome. This study was conducted to investigate the prevalence and demographic profile of FS in patients with idiopathic/generalized and focal/self-limited epilepsies.

Methods: This retrospective study included all of the patients with normal developmental assessments who were admitted to our outpatient clinic with idiopathic/generalized and focal/self-limited epilepsy. The data were collected from their medical and electroencephalogram records. The patients were subgrouped according to their syndromes and the presence of FS. Comparisons were made for the characteristics of FS.

Results: Among 320 patients with the diagnosis of focal or generalized epilepsy with presumed genetic cause, FSs were present in $14.7 \%$ $(n=47)$ of them without gender preponderance. Self-limited focal epilepsy was present in 232 children (72.5\%). The mean age of epilepsy onset was $7.97 \pm 3.38$ years (range: $1-18$ years). Although the distribution of FSs in focal or generalized epilepsy groups $(p=0.552)$ and subtypes of these groups $(p=0.701)$ did not indicate any statistical significance, highest ratios of FS occurrence were found in juvenile myoclonic epilepsy and idiopathic photosensitive occipital lobe epilepsy groups.

Conclusion: Gender, family history of epilepsy and FS, onset age of epilepsy, type of epilepsy did not seem as a predictor factor for subsequent epilepsy in the patients with FS otherwise normal children.
\end{abstract}

Keywords: Febrile seizure; focal/self-limited epilepsy; idiopathic/generalized epilepsy.

Cite this article as: Tümay F, Nalbantoglu M, İnan R, Yavlal F, Demirbilek V. Febrile Seizures in Idiopathic/Genetic Generalized and Self-Limited Focal Epilepsies. Epilepsi 2021;27:113-118.

\section{Introduction}

Febrile seizure (FS) is defined by the International League against Epilepsy (ILAE) as a type of seizure associated with the fever arising from an infection outside the central nervous system in the absence of acute electrolyte imbalance

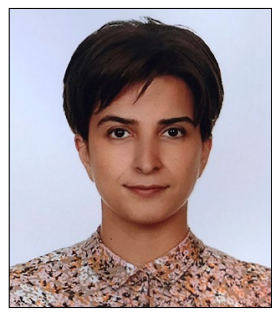

Corresponding author Rahşan INAN, M.D. e-mail rahinan@yahoo.com

Received 25.04.2020

Accepted 09.11.2020

Online date 02.04.2021

Content of this journal is licensed under a Creative Commons Attribution-NonCommercial 4.0 International License.

C 2021 Turkish Epilepsy Society or prior afebrile seizures (AFSs). The lower age limit refers to being older than 1 month of age. ${ }^{[1]}$ Although the definition lacks an upper age limit, presentation after 7 years of age is quite rare. Mostly, FS occurs between 6 months and 5 years of age with the peak incidence at 18 months. ${ }^{[2,3]}$

FS is the most common form of childhood seizure. ${ }^{[4]}$ Its prevalence ranges from $2 \%$ to $4 \%$ in the western countries with an ethnic variability (9-10\% for Japanese, and up to $14 \%$ in Guam) ${ }^{[3]}$ It reoccurs in one-third of the children and its association with epilepsy is low (2.4\% of the neurologically normal children with FS compared to $1.4 \%$ of general population). ${ }^{[5]}$ Genetic (especially genes coding ion channels) and environmental factors are considered to be responsible for FS. ${ }^{[6,7]}$

In terms of epilepsy, traditionally, the idiopathic/presumed genetic cause was used to implicate the age-related onset, 


\section{İdiyopatik/Genetik Jeneralize ve Kendini Sınırlayan Fokal Epilepsilerde Febril Nöbetler}

\section{$\ddot{0} z$}

Amaç: Febril nöbet (FN) çocukluk çağı döneminin en sık görülen nöbet tipidir. İdiyopatik/jeneralize ve fokal/ kendini sınırlayan nöbetler de aynı yaş grubunda izlenmektedir. Genellikle iyi seyirlidirler. Bu çalışma idiyopatik/jeneralize ve fokal/ kendini sınırlayan epilepsileri olan hastalarda FN prevalansı ve demografik profili araştırmak amacıyla yapıımıştır.

Gereç ve Yöntem: Bu geriye dönük çalışmaya polikliniğimize başvurmuş, gelişimsel değerlendirmeleri normal olan idiyopatik/jeneralize ve fokal/ kendini sınırlayan epilepsileri olan hastalar dahil edildi. Veriler hastaların tıbbi ve EEG kayıtlarından toplandı. Hastalar sendromlarına ve FN varlığına göre alt gruplara ayrıldı. Karşılaştırmalar FN özelliklerine göre yapıldı.

Bulgular: Fokal ya da olası genetik nedenli jeneralize epilepsi tanılı 320 hasta arasında, FN'ler cinsiyet üstünlüğü olmaksızın \%14.7 (n=47)

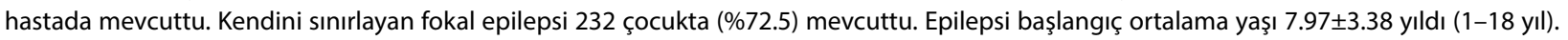
FN'lerin fokal ya da jeneralize epilepsi grupları $(p=0.552)$ ya da bu grupların alt tipleri $(p=0.701)$ içindeki dağılımı istatiksel anlamlılık göstermemekle birlikte, FN varlığı en yüksek oranla jüvenil miyoklonik epilepsi ve idiyopatik fotosensitif oksipital lob epilepsi gruplarında bulundu. Sonuç: Cinsiyet, FN ya da epilepsi aile öyküsü, epilepsi başlangıç yaşı, epilepsi tipi FN dışında normal olan çocuklarda ortaya çıkacak epilepsi için belirleyici bir faktör olarak görünmemektedir.

Anahtar sözcükler: Febril nöbet; fokal/ kendini sınırlayan epilepsi; idiyopatik/jeneralize epilepsi.

highly pharmacoresponsive characteristics and a presumed genetic background for children. ${ }^{[8]}$ Considering these features, presumed genetic background and favorable outcome seems to be common for childhood epilepsies and FS. The present study aimed to investigate the frequency of FS in focal/self-limited and idiopathic/generalized childhood epilepsies to explore the relationship between FS and epilepsy.

\section{Materials and Methods}

This was a retrospective cross-sectional study conducted at Cerrahpaşa School of Medicine, Pediatric Neurology Clinics of Neurology Department. The medical records of all patients followed in our outpatient clinic with diagnosis of idiopathic/genetic epilepsy beginning at pediatric age were investigated retrospectively. Their medical histories and family histories including epilepsy and FS were examined. The inclusion criteria were composed of having idiopathic/ genetic childhood epilepsy along with normal birth history, normal neurological examination, and normal developmental assessments including cognitive, speech, and motor skills. For each patient, parameters such as gender, onset age of epilepsy, seizure type (focal/generalized), and history of FSs were collected from their medical records.

The diagnosis of epilepsy was made on the basis of clinical and electroencephalogram (EEG) findings as recommended by the Commission on Classification and Terminology of the ILAE, 2017. ${ }^{[9-11]}$ Patients were initially classified into two groups according to the mode of seizure onset, namely, focal and generalized seizures. Epilepsy syndrome diagnosis was made on the basis of age of seizure onset, seizure types, and EEG characteristics. Patients having focal epilepsy were sub- grouped as childhood epilepsy with centrotemporal spikes, Panayiotopoulos syndrome, childhood occipital epilepsy (Gastaut type), and idiopathic photosensitive occipital lobe epilepsy (IPOE). Patients with generalized epilepsy were subgrouped as childhood absence epilepsy (CAE) and juvenile myoclonic epilepsy (JME). The inclusion criteria for FSs were having seizures triggered exclusively by high fever without evidence of infection of the central nervous system. ${ }^{[1]}$

The Statistical Package for the Social Sciences (SPSS, Chicago, IL, U.S.A.). was used for statistical analysis. The differences among demographic variables were analyzed by means of Chi-square test for nominal variables, Mann-Whitney $U$, and Kruskal-Wallis test for nonparametric variables. $\mathrm{P} \leq 0.05$ was taken to indicate a statistical significance.

\section{Results}

A total of 320 patients with the diagnosis of focal/self-limited or generalized epilepsy were included in this study. Of these, $51.9 \%(n=166)$ were boys. The mean age of epilepsy onset was $7.97 \pm 3.38$ years (ranging from 1 to 18 years). The mean age at last visit was $21.63 \pm 7.16$ years (ranging from 1 to 56 years).

The majority of the patients $(72.5 \%, n=232)$ had focal/ self-limited epilepsy. The distribution of epilepsy subtypes is shown in Table 1.

Among the whole group, FS were reported in $14.7 \%(n=47)$ of the patients. The rate of FS was similar for boys (15.7\%, $\mathrm{n}=26)$ and girls $(13.6 \%, \mathrm{n}=21)(\mathrm{p}=0.362)$. The onset age of epilepsy did not show significant difference in the presence of FS $(p=0.611)$. 
Table 1. Distribution of epilepsy subtypes

\begin{tabular}{llcc}
\hline & & $\mathrm{n}$ & $\%$ \\
\hline \multirow{2}{*}{ Focal/Self-limited } & Childhood epilepsy with centrotemporal spikes & 86 & 26.9 \\
& Panayiotopoulos syndrome & 76 & 23.8 \\
& Childhood occipital epilepsy (gastaut type) & 42 & 13.1 \\
& Idiopathic photosensitive occipital lobe epilepsy & 28 & 8.8 \\
Generalized & Childhood absence epilepsy & 53 & 16.6 \\
& Juvenile myoclonic epilepsy & 35 & 10.9 \\
\hline
\end{tabular}

Table 2. Frequency of febrile seizures in epilepsy groups

\begin{tabular}{|c|c|c|c|c|c|}
\hline \multirow[t]{2}{*}{ Epilepsy groups } & \multicolumn{2}{|c|}{$\mathrm{FS}(+)$} & \multicolumn{2}{|c|}{$\mathrm{FS}(-)$} & \multirow[t]{2}{*}{$p$-value } \\
\hline & $\mathrm{n}$ & $\%$ & $\mathrm{n}$ & $\%$ & \\
\hline Focal/Self-limited & 34 & 14.7 & 198 & 85.3 & 0.552 \\
\hline Generalized & 13 & 14.8 & 75 & 85.2 & \\
\hline
\end{tabular}

Table 3. Frequency of febrile seizures in epilepsy subgroups

\begin{tabular}{lccccccc}
\hline \multirow{2}{*}{ Epilepsy subgroups } & \multicolumn{2}{c}{$\mathrm{FS}(+)$} & & \multicolumn{2}{c}{$\mathrm{FS}(-)$} & \multirow{2}{*}{ p-value } \\
\cline { 2 - 3 } & $\mathrm{n}$ & $\%$ & & $\mathrm{n}$ & $\%$ & \\
\hline Childhood epilepsy with centrotemporal spikes & 10 & 11.6 & & 76 & 88.4 & 0.701 \\
Panayiotopoulos syndrome & 12 & 15.8 & & 64 & 84.2 & \\
Childhood occipital epilepsy (gastaut type) & 6 & 14.3 & & 36 & 85.7 & \\
Idiopathic photosensitive occipital lobe epilepsy & 6 & 21.4 & & 22 & 78.6 & \\
Childhood absence epilepsy & 6 & 11.3 & & 47 & 88.7 & \\
Juvenile myoclonic epilepsy & 7 & 20 & & 28 & 80 & \\
\hline
\end{tabular}

The ratio of the patients with family history of epilepsy was $25.6 \%(n=82)$ while the ratio of the patients with family history of FSs was $15 \%(n=48)$.

The rate of having familial history of FS, although not significant, was more frequent in patients with FS (19.1\%) than those without FS (14.3\%) $(p=0.254)$. The presence of familial history of epilepsy was similar among patients with (23.4\%) and without FS $(26 \%)(p=0.430)$.

The frequency of FSs according to the epilepsy subtypes is given in Tables 2 and 3. Neither the focal/self-limited and generalized epilepsy groups $(p=0.552)$ nor the subtypes of these groups did show significant difference in terms of $F S$ frequency $(p=0.701)$.

\section{Discussion}

OFSs are the most common and usually benign seizures of infancy and childhood. Childhood epilepsies, which mostly have a favorable outcome, also present at the similar age- range. Both entities seem to have a genetical background in their pathologies. ${ }^{[12,13]}$ Since FSs are benign with an excellent neurologic outcome and low risk of epilepsy, ${ }^{[14]}$ children with simple FS have approximately the same risk of developing epilepsy by the age of 7 years as the general population. ${ }^{[15,16]}$ The risk factors for epilepsy development include an antecedent neurologic or developmental abnormality, a positive family history of epilepsy, multiple simple FSs, a complex FS (especifically focal FS) and an onset of FSs before 1 year of age. ${ }^{[2,16-19]}$ However, FS cases with preceding positive spikes observed in their EEGs were demonstrated to evolve into epilepsy. ${ }^{[20]}$

Having a normal neurological or developmental status was an inclusion criteria in the present study. Determining the type and numbers of FS exactly in each patient, which could have helped to understand the effect of FS type association with subsequent epilepsy development, could not be succeeded due to the retrospective design of the study. Nevertheless, the long-term outcome for subsequent epilepsy 
was reported to be not influenced by the number or type of FSs. ${ }^{[16,17,21]}$ Offringa et al. ${ }^{[22]}$ reported the ratio of having a family history of FS as $24 \%$ in children with FS while the ratio of having a family history of epilepsy was around $4 \%$. The presence of familial history of FS and epilepsy was similar among patients with and without FS in the present study (19.1\% and $23.4 \% ; 14.3 \%$ and $26 \%$, respectively). Accordingly, the family history of FS and epilepsy did not seem to be a risk factor for epilepsy development.

Camfield et al. ${ }^{[23]}$ suggested that $13-19 \%$ of children with AFSs had one or more previous FS. The rate of previous FS (14.7\%) was found to be quite similar in our patient group. They also showed that the rate of preceding FSs did not vary with the cause of epilepsy and that FSs most often preceded generalized tonic-clonic AFSs. We did not find any significant differences among the epilepsy groups in terms of FS frequency.

Out of 320 children, $14.7 \%(n=47)$ had FS. This ratio was higher than that of the general population which was reported between $2 \%$ and $5 \%$ in the western world and $3.5 \%$ and $9 \%$ in Turkey. ${ }^{[24-26]}$ Although ethnic, genetic background or environmental conditions lead to variability among different geographies and knowing that prevalence of FS is higher in developing countries than in developed ones, this ratio still seems high. The reported ratios in the literature are the results of the studies with larger sample size. Hence, our finding may be misleading in that sense. Moreover, arising from the retrospective design of the study (FS history was retrieved from the past medical records), it is a controversial issue whether these seizures are really FS or the seizures triggered by fever.

The frequency of FS did not differ significantly between focal/self-limited and generalized epilepsy groups (ranging between $11.6 \%$ and $21.4 \%$ and $11.3 \%$ and $20 \%$, respectively) supporting the previous literature on the subject. IPOE in focal/self-limited group and JME in generalized group were the epileptic syndromes with the highest ratios of FS occurrence. Considering focal/self-limited epilepsies, reported occurrence of FSs was around 18\% in childhood epilepsy with centrotemporal spikes, ${ }^{[27]} 17 \%$ in Panayiotopoulos syndrome, ${ }^{[28]}$ and $10 \%$ in childhood occipital epilepsy of Gastaut type. ${ }^{[29]}$ The cohort studies examining generalized epilepsy patients did not reveal any significant difference between generalized and focal epilepsies. Another study analyzing the long-term outcomes of the patients with CAE reported that $7.7 \%$ of patients had a history of FS. ${ }^{[30]}$ There are also some studies reporting the frequency of FS in CAE as high as $20-22 \%$ and $13 \%$ in JME in the literature. ${ }^{[31]}$ Furthermore, a mutation in a gene encoding a $\operatorname{GABA}(\mathrm{A})$ receptor subunit was found in families with epilepsy where the two main phenotypes were $C A E$ and $\mathrm{FS}^{[32,33]}$ indicating the genetic relationship between these two syndromes.

Although there was no significant difference in terms of FS frequency within subgroups of epilepsy syndromes, the highest rates, a remarkable finding, were noted in IPOE and JME groups. Photosensitivity is the common feature of these syndromes. The literature has limited number of studies investigating photosensitivity in patients with FS. One study analyzing the photosensitivity in patients with the most common epileptic syndrome revealed that $23 \%$ of 117 patients with FS had photosensitivity. ${ }^{[34]}$ This ratio reached up to $42 \%$ in a long-term EEG follow-up study. ${ }^{[35]}$ Doose interpreted the photosensitivity as the symptom of genetically independent pathogenetic mechanism which could lead to some additive effects by interacting with other genetic abnormalities as well as exogenous factors, thus denoting that the pathogenesis of febrile convulsions was multifactorial in the strict sense. Based on this finding, a relationship between the photosensitivity and susceptibility to FSs, which may warrant further analysis, may be suggested. However, we should stress that our study could not recognize possible underlying factors in terms of photosensitivity.

It is known that focal seizures may coexist with generalized myoclonic seizures in IPOE. Moreover, Dravet syndrome is characterized with FSs in infancy and myoclonic seizures in the following years. Channelopathy is the common etiological factor among these syndromes. Since the ratio of FS was highest in the epilepsy syndromes with myoclonic seizures in our patient group, we may hypothesize that risk of subsequent development of myoclonic epilepsy is high in FS patients due to this shared etiology of channelopathy.

Conclusion- FSs, although accepted benign, can be a predisposing factor for the development of epilepsy. Gender, family history of epilepsy and FS, onset age of epilepsy, type of epilepsy do not seem as predicting factors for subsequent epilepsy in the patients with FS who were otherwise normal. Additional studies are needed to evaluate the relationship of FSs with photosensitive and myoclonic epilepsies.

Although children with seizures having various etiologies comprise a significant burden in inpatient clinics, the longterm prognosis of epilepsy is favorable in the majority of 
children, especially for those with idiopathic etiology. Since the FSs are the most common types of childhood seizures, proper prospective studies on clinicodemographic profile of seizures are required for better understanding the disease burden and to take appropriate measures for its control.

Acknowledgment- This research received no specific grant from any funding agency in the public, commercial, or not-for-profit sectors.

Informed Consent- Due to the retrospective design of the study, informed consent was not taken.

Peer-review- Externally peer-reviewed.

Authorship Contributions- Concept: F.B.T., M.N., V.D.; Design: F.B.T., M.N., V.D.; Supervision: R.I., F.Y., V.D.; Data collection \&/or processing: F.B.T., M.N.; Analysis and/or interpretation: F.B.T., M.N., R.I.., F.Y., V.D.; Literature search: F.B.T., M.N.; Writing: F.B.T., M.N., R.I.., F.Y., V.D.; Critical review: F.B.T., M.N., R.I., F.Y., V.D.

Conflict of interest-The authors declare that they have no conflict of interest.

Financial Disclosure: The authors declared that this study has received no financial support.

\section{References}

1. Commission on Epidemiology and Prognosis International League Against Epilepsy. Guidelines for epidemiologic studies on epilepsy. Epilepsia 1993;34(4):592-6. [CrossRef]

2. Waruiru C, Appleton R. Febrile seizures: An update. Arch Dis Child 2004;89(8):751-6. [CrossRef]

3. Shinnar S, Glauser TA. Febrile seizures. J Child Neurol 2002;17(1):S44-52. [CrossRef]

4. Lux AL. Treatment of febrile seizures: Historical perspective, current opinions, and potential future directions. Brain Dev 2010;32(1):42-50. [CrossRef]

5. Sadleir LG, Scheffer IE. Febrile seizures. BMJ2007;334(7588):30711. [CrossRef]

6. Kjeldsen MJ, Kyvik KO, Friis ML, Christensen K. Genetic and environmental factors in febrile seizures: A Danish population-based twin study. Epilepsy Res 2002;51(1-2):167-77.

7. Paul SP, Blaikley S, Chinthapalli R. Clinical update: Febrile convulsion in childhood. Community Pract 2012;85(7):36-8.

8. Panayiotopoulos CP. Idiopathic epileptic seizures and syndromes in infancy. In: Panayiotopoulos $\mathrm{CP}$, editor. A Clinical Guide to Epileptic Syndromes and their Treatment. London: Springer-Verlag; 2010. p. 259-74. [CrossRef]

9. Scheffer IE, Berkovic S, Capovilla G, Connolly MB, French J, Guilhoto $\mathrm{L}$, et al. ILAE classification of the epilepsies: Position paper of the ILAE commission for classification and terminology. Epilepsia 2017;58(4):512-21. [CrossRef]
10. International League Against Epilepsy. Definitions and Guidelines on Epilepsy from ILAE; 2017. Available at: http://www.ilae. org/visitors/centre/definition_class.cfm. Accessed May 18, 2017.

11. Aaberg KM, Surén $\mathrm{P}$, Søraas $\mathrm{CL}$, Bakken IJ, Lossius $\mathrm{MI}$, Stoltenberg $C$, et al. Seizures, syndromes, and etiologies in childhood epilepsy: The international league against epilepsy 1981, 1989, and 2017 classifications used in a populationbased cohort. Epilepsia 2017;58(11):1880-91. [CrossRef]

12. Nakayama J, Arinami T. Molecular genetics of febrile seizures. Epilepsy Res 2006;70(1):S190-8. [CrossRef]

13. Kananura C, Haug K, Sander T, Runge U, Gu W, Hallmann K, et al. A splice-site mutation in GABRG2 associated with childhood absence epilepsy and febrile convulsions. Arch Neurol 2002;59(7):1137-41. [CrossRef]

14. Leung AK, Robson WL. Febrile seizures. J Pediatr Health Care 2007;21(4):250-5. [CrossRef]

15. Nelson KB, Ellenberg JH. Predictors of epilepsy in children who have experienced febrile seizures. $N$ Engl J Med 1976;295(19):1029-33. [CrossRef]

16. Baumann RJ, Duffner PK. Treatment of children with simple febrile seizures: The AAP practice parameter. American academy of pediatrics. Pediatr Neurol 2000;23(1):11-7. [CrossRef]

17. Trinka E, Unterrainer J, Haberlandt E, Luef G, Unterberger I, Niedermüller $\mathrm{U}$, et al. Childhood febrile convulsions-which factors determine the subsequent epilepsy syndrome? A retrospective study. Epilepsy Res 2002;50(3):283-92. [CrossRef]

18. Verity $\mathrm{CM}$, Golding J. Risk of epilepsy after febrile convulsions: A national cohort study. BMJ 1991;303(6841):1373-6. [CrossRef]

19. Annegers JF, Hauser WA, Shirts SB, Kurland LT. Factors prognostic of unprovoked seizures after febrile convulsions. N Engl J Med 1987;316(9):493-8. [CrossRef]

20. Yoshinaga H, Kobayashi K, Akiyama T, Shibata T, Endoh F, Ohtsuka Y. Clinical implications of preceding positive spikes in patients with benign partial epilepsy and febrile seizures. Brain Dev 2013;35(4):299-306. [CrossRef]

21. Knudsen, FU, Paerregaard A, Andersen R, Andresen J. Long term outcome of prophylaxis for febrile convulsions. Arch Dis Child 1996;74(1):13-8. [CrossRef]

22. Offringa $M$, Bossuyt PM, Lubsen J, Ellenberg JH, Nelson $K B$, Knudsen FU, et al. Risk factors for seizure recurrence in children with febrile seizures: A pooled analysis of individual patient data from five studies. J Pediatr 1994;124(4):574-84. [CrossRef]

23. Camfield P, Camfield C, Gordon K, Dooley J. What types of epilepsy are preceded by febrile seizures? A population-based study of children. Dev Med Child Neurol 1994;36(10):887-92.

24. Canpolat M, Per H, Gumus H, Elmali F, Kumandas S. Investigating the prevalence of febrile convulsion in Kayseri, Turkey: An assessment of the risk factors for recurrence of febrile convulsion and for development of epilepsy. Seizure 2018;55:36-47. [CrossRef]

25. Ateşoğlu $M$, İnce $T$, Lüleci $D$, Ergör $A$, Aydın A. Sociodemographic risk factors for febrile seizures: A school-based study from Izmir, Turkey. Seizure 2018;61:45-9. [CrossRef] 
26. Aydin A, Ergor A, Ozkan H. Effects of sociodemographic factors on febrile convulsion prevalence. Pediatr Int 2008;50(2):216-20.

27. Kajitani T, Kimura T, Sumita M, Kaneko M. Relationship between benign epilepsy of children with centro-temporal EEG foci and febrile convulsions. Brain Dev 1992;14(4):230-4. [CrossRef]

28. Panayiotopoulos CP. Panayiotopoulos Syndrome: A Common and Benign Childhood Epileptic Syndrome. London: John Libbey \& Company; 2002.

29. Panayiotopoulos CP, Michael M, Sanders S, Valeta T, Koutroumanidis M. Benign childhood focal epilepsies: Assessment of established and newly recognized syndromes. Brain 2008;131(9):2264-86. [CrossRef]

30. Martínez-Ferrández C, Martínez-Salcedo E, Casas-Fernández C, Alarcón-Martínez H, lbáñez-Micó S, Domingo-Jiménez R. Longterm prognosis of childhood absence epilepsy. Neurologia 2019;34(4):224-8. [CrossRef]
31. Durón RM, Medina MT, Martínez-Juárez IE, Bailey JN, PerezGosiengfiao KT, Ramos-Ramírez R, et al. Seizures of idiopathic generalized epilepsies. Epilepsia 2005;46(9):34-47. [CrossRef]

32. Marini C, Harkin LA, Wallace RH, Mulley JC, Scheffer IE, Berkovic SF. Childhood absence epilepsy and febrile seizures: A family with a GABA(A) receptor mutation. Brain 2003;126(1):23040.

33. Wallace RH, Marini C, Petrou S, Harkin LA, Bowser DN, Panchal RG, et al. Mutant GABA(A) receptor gamma2-subunit in childhood absence epilepsy and febrile seizures. Nat Genet 2001;28(1):49-52. [CrossRef]

34. Lu Y, Waltz S, Stenzel K, Muhle H, Stephani U. Photosensitivity in epileptic syndromes of childhood and adolescence. Epileptic Disord 2008;10(2):136-43.

35. Doose H, Ritter K, Völzke E. EEG longitudinal studies in febrile convulsions. Genetic aspects. Neuropediatrics 1983;14(2):81-7. 